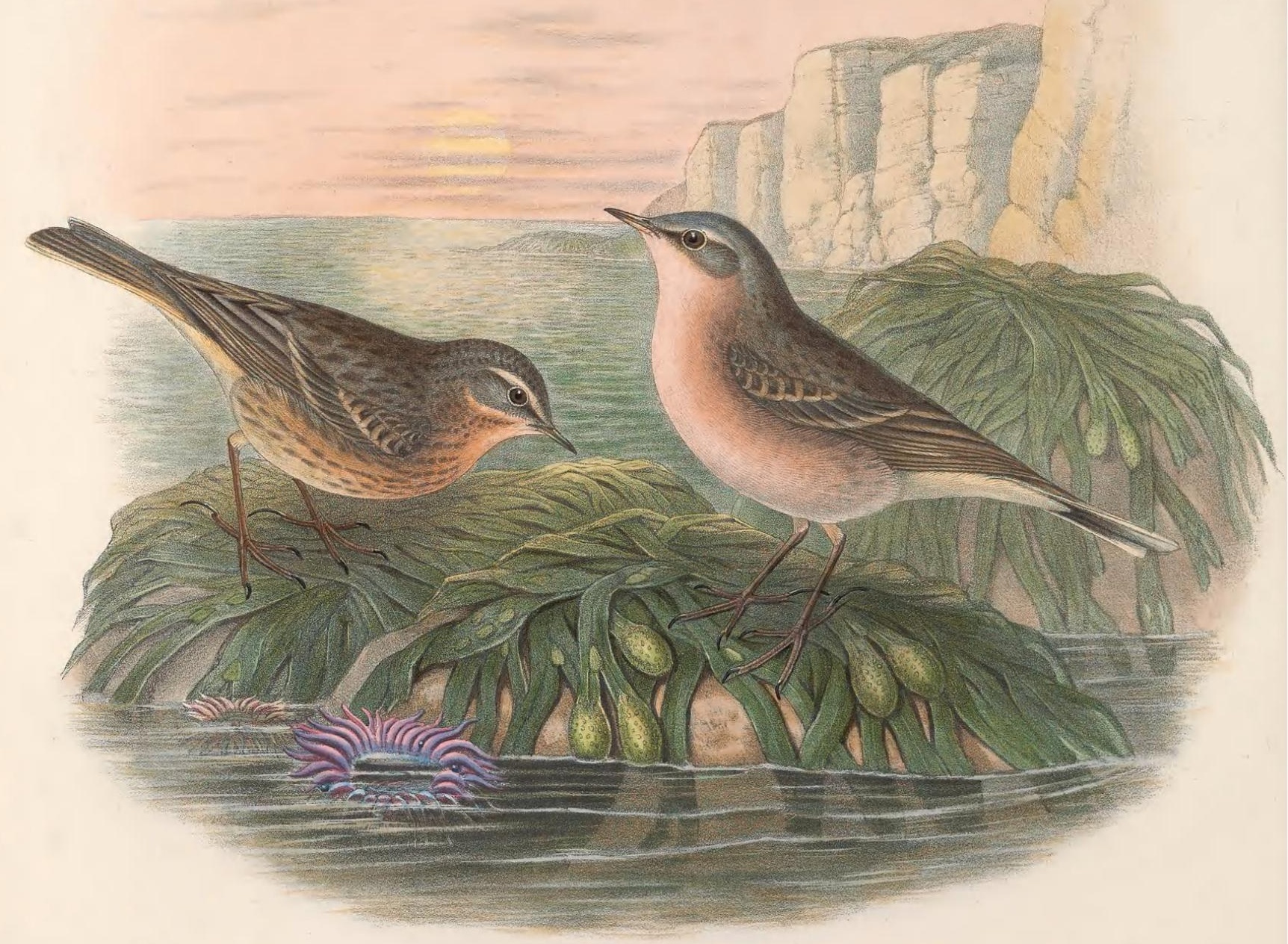




\section{ANTHUS SPINOLET'TA.}

\section{Vinous Pipit.}

Alauda spinoletta, Linn. Syst. Nat., tom. i. p. 288.

Anthus spinoletta, Bonap. Syn. Birds of Am., p. 90.

aquaticus, Bechst. Naturg. Deutschl., tom. iii. p. 745.

montanus, Koch, Baier. Zool., tom. i. p. 172 ?

THE Pipits with vinous-coloured breasts which have for some years past been killed in England, have been a sad puzzle to our ornithologists - some being of opinion that they are a variety of Anthus obscurus, and others that they pertain to a distinct species; more than one regard them as identical with the Anthus ludovicianus of America, while others believe them to be examples of the A. spinoletta of Linnæus (A. aquaticus of Temminck). In this latter opinion I coincide; hence it becomes necessary that I should give a figure of the bird, and all the information I can respecting it. On the 25th of January 1860, Mr. Murray A. Matthews, of Merton College, Oxford, wrote to me as follows :- "Are there two species of Rock-Pipit in this country, of which one has hitherto remained unnoticed? or is the continental Rock-Pipit (A. aquaticus, Temm.) merely a permanent variety of the ordinarily olive-coloured Pipit (A. obscurus) met with with us? I possess a Rock-Pipit shot at Torquay, which appears to me to be slightly larger than the bird commonly seen, and of a rich vinous tint on the breast. I thought at first this might be a very old bird, in an advanced state of plumage, and was careful therefore to shoot, last spring, during the breeding-season (when the birds would certainly be in their finest state), a number of specimens for comparison ; but none of those I then shot bore any resemblance in the tint of their plumage to my Torquay specimen. The ordinary RockPipit, so abundant on our coasts, is known at once by its sombre olive-green colouring, and by the welldefined gorget of spots on its throat. In the Torquay specimen there is hardly any trace of this gorgetmarking."

In December 1864, the Messrs. Pratt, of Brighton, sent for my inspection two vinous-breasted birds, one of which, killed near Worthing, is represented in the front figure of my Plate. Some time after this, Mr. Edward T. Booth wrote to Mr. Bond:- "Mr. Swaysland has seen ten of these birds this season; of that number he obtained eight one morning, and two more in three or four mornings afterwards, between the 14th and 20th of March 1867, at a small salt-pool just inside the sea-beach at Portslade, near Brighton. Some of them were seen crossing the sea, and pitching on the grass near the pool. They were by no means shy, but would not permit a nearer approach than about thirty or forty yards. A great number of other Pipits were crossing at the same time, all of which appeared to be the MeadowPipit." Two of these specimens having been sent to Mr. Bond, that gentleman allowed me to inspect them, and I found they were precisely similar to the Anthus spinoletta of the Continent: one had the breast strongly suffused with vinous; in the other this tint was not so extensive, the flanks being spotted with brown, from which we may infer that it was a younger bird, or one beginning to assume its summer plumage ; for it is believed that the vinous tint is a characteristic of the $A$. spinoletta at that season; and it seems to me that these birds must be distinct from $A$. obscurus, because we do know that the examples of the latter species so generally distributed over this country retain the spotted plumage throughout the year. I suspect that most of the Pipits of the northern hemisphere differ in the same manner as the Wagtails, and that, if we admit Motacilla Yarrelli to be distinct from M. alba, and Budytes Rayi from B. Alava, we must also regard the present bird, $A$. spinoletta, as distinct from A. obscurus.

According to Bailly, the $A$. spinoletta passes much of its time and breeds on the mountains-a habit so different from that of $A$. obscurus that his account, extracted from his 'Ornithologie de la Saroie,' tends greatly to prove that it is a distinct species.

"This bird is common, at all seasons of the year, both in Switzerland and in Savoy. During winter it frequents the wet meadows, the marshes, and the unfrozen springs of the lower portions of both those countries, and about the end of March or beginning of April ascends the mountains and resorts to the most sterile plateaux, fields, heaths, and stony places in the neighbourhood of water, often above the forest-region. It generally proceeds in small companies, and ascends a short distance every day as the snows disappear from its favourite breeding-places. It pairs at the beginning of May; and the united couples immediately begin the construction of their nests. These are to be found on all parts of the mountains, even near to the line of perpetual congelation-sometimes in declivities, at others on the plateaux, but nearly always in the most arid and desert places. They are placed on the ground, under stones, sometimes in clefts in the rock, but oftener in the grass, beneath the bilberry, Rhododendron ferrugineum, whortleberry, or some creep- 
ing bush. Very fine straw, hay, the finer tendrils of the roots of plants and shrubs, and bits of moss compose the exterior; hair, small tufts of sheep's wool, and filaments of dried grass the interior. The eggs, which are four or five in number, are sometimes greyish white, at others pale greenish white, covered with small irregular spots of deep brown and greenish olive, placed so thickly at the larger end that the ground-colour is scarcely perceptible.

"Sometimes a second but less numerous brood is produced. The young scatter themselves over the meadows, the borders of pools, springs, and miry places, where they feed upon worms, maggots, flies, and snails. At times, and especially in the morning, the birds assemble on some spot exposed to the first rays of the sun, and there form a numerous company, which, as the beams become more ardent, gradually disperse into damp or shady places. On the approach of an intruder they all rise one after another, uttering warning cries of $f t, f i, f t, f i$. At the end of September or a little later, acording to the season, they descend from the mountains singly, in pairs, or in small flocks, to the damp fields covered with verdure, artificial meadows, winding streams, and the borders of ponds and marshes. They are nearly always on the ground, often in company with Meadow-Pipits, running like them over the mud and the leaves of aquatic plants, in search for insects, small worms, prawns, and little shell-fish upon which they subsist. As soon as the cold becomes intense, they betake themselves to the bogs and the borders of springs and other waters that are not frozen, and pass the nights in the holes of trees, especially willows. When all other food fails from the severity of the weather, they have recourse to the smallest seeds or berries of the plants which grow near water, and swallow them whole. Should the winter continue unusually rigorous, they leave the country entirely, and return again when the snows have melted. This bird is somewhat more wild than its congeners, does not allow of a near approach, but is easily captured with nets, if one or two of its kind be employed as decoys." flanks olive.

Head and back of the neck grey; upper surface olive, with a dark-brown centre to each feather; wings dark brown, the coverts broadly tipped with buffy grey, forming two bands; axillaries greyish white; primaries very narrowly edged with pale olive; tail dark brown, the outermost feathers with an oblique mark of white along the apical portion of the outer web and the tip of the inner one; the next on each side with a small patch of white at the tip; superciliary stripe greyish white, lores and ear-coverts grey; under surface vinous, passing into buff on the centre of the abdomen, which again fades into the white of the under tail-coverts;

In another state the upper surface is similar, but the under surface differs in having the throat vinous, and a series of brown streaks down each side of it, while the abdomen is greenish yellow, streaked with brown on the upper part of the flanks, and the white mark on the tail feathers is much less conspicuous.

The figures are of the size of life. 


\section{$2 \mathrm{BHL}$ Biodiversity Heritage Library}

Gould, John. 1873. "Vinous Pipit, Anthus spinoletta [PI. 11]." The birds of Great Britain 3, -. https://doi.org/10.5962/p.323902.

View This Item Online: https://www.biodiversitylibrary.org/item/221726

DOI: https://doi.org/10.5962/p.323902

Permalink: https://www.biodiversitylibrary.org/partpdf/323902

\section{Holding Institution}

Smithsonian Libraries

\section{Sponsored by}

Biodiversity Heritage Library

\section{Copyright \& Reuse}

Copyright Status: Public domain. The BHL considers that this work is no longer under copyright protection.

This document was created from content at the Biodiversity Heritage Library, the world's largest open access digital library for biodiversity literature and archives. Visit BHL at https://www.biodiversitylibrary.org. 